\title{
Analisis Perubahan Penggunaan Air Bersih Sebelum dan Sesudah Terjadi Kenaikan Tarif PDAM di Kabupaten Bangli
}

\author{
Analysis of Changes in Clean Water Use Before and After the Increase in \\ PDAM Rates in Bangli Regency
}

\author{
Mawiti Infantri Yekti $^{\left.{ }^{*}\right)}$, I Gusti Ngurah Kerta Arsana ${ }^{1}$, Made Dwita Berlian Aryasavira ${ }^{1}$ \\ ${ }^{1}$ Jurusan Teknik Sipil, Fakultas Teknik, Universitas Udayana, Bali, Indonesia
}

Article info:

Kata kunci:

kenaikan tarif, PDAM kabupaten bangli, penggunaan air bersih, trend

Keywords:

cost increment, PDAM bangli regency, the use of clean water, trend

Article history:

Received: 10-09-2019

Accepted: 23-05-2020

*)Koresponden email: wiwiet91@yahoo.com
Abstrak

Di tahun 2013 Pemerintah Kabupaten Bangli serta PDAM Kabupaten Bangli sepakat untuk membuat kebijakan baru terkait dengan kenaikan tarif air bersih di Kecamatan Bangli dan Tembuku. Penelitian ini bertujuan memunculkan trend perubahan sebelum dan sesudah kenaikan tarif PDAM sebesar 118\%, sehingga dapat dijadikan landasan pengambilan keputusan PDAM Bangli selanjutnya. Penelitian ini menggunakan metode simple random sampling dengan mengambil secara acak sampel yang diteliti tanpa melihat strata yang ada, dan sampel tersebar sebanyak 80 sampel di Kecamatan Bangli dan sebanyak 75 sampel di Kecamatan Tembuku. Hasil analisis menunjukkan penggunaan air bersih mengalami trend penurunan sesudah kenaikan tarif yaitu $25.28 \%$ berdasarkan survei dan $25.31 \%$ berdasarkan ketetapan PDAM di Kecamatan Bangli. Sedangkan di Kecamatan Tembuku menunjukkan trend sebaliknya yaitu meningkat sesudah kenaikan tarif sebesar $14.08 \%$ berdasarkan survei dan $14.07 \%$ berdasarkan ketetapan PDAM. Perubahan penggunaan air bersih rata-rata per orang/hari tersebut dipengaruhi kebutuhan air berdasarkan jumlah anggota keluarga di setiap rumah per bulan.

\begin{abstract}
In 2013 the Bangli Regency Government and the Bangli Regency PDAM agreed to make a new policy related to the increasing of clean water tariffs in the Bangli and Tembuku Districts. This study aims to bring up the trend of changes before and after the PDAM tariff increase of $118 \%$, so that it can be used as a basis for further Bangli PDAM decision making. This study uses a simple random sampling method by randomly taking the samples studied without looking at the strata, and samples are scattered as many as 80 samples in Bangli District and as many as 75 samples in Tembuku District. The analysis showed that the use of clean water experienced a declining trend after the tariff increase of $25.28 \%$ based on the survey and $25.31 \%$ based on the provision of the PDAM in the Bangli District. Whereas in Tembuku District the reverse trend showed an increase after the tariff increase of $14.08 \%$ based on the survey and $14.07 \%$ based on the provision of the PDAM. Changes in the use of clean water on average per person/day is influenced by water needs based on the number of family members in each house per month.
\end{abstract}


Kutipan: Infantri Yekti, M., Gusti Ngurah Kerta Arsana, I., \& Dwita Berlian Aryasavira, M. (2020). Analisis Perubahan Penggunaan Air Bersih Sebelum Dan Sesudah Terjadi Kenaikan Tarif Pdam Di Kabupaten Bangli. Jurnal Teknik Pengairan. https://doi.org/10.21776/ub.pengairan.2020.011.01.04

\section{Pendahuluan}

Provinsi Bali merupakan salah satu daerah pariwisata, yang dimana penggunaan akan air bersih menjadi sangat tinggi untuk setiap harinya. Salah satu kabupaten yang terdapat di Provinsi Bali adalah Kabupaten Bangli. Perkembangan pembangunan yang cukup pesat di Kabupaten Bangli menyebabkan banyaknya orang luar masuk ke daerah tersebut. Hal ini juga dapat menjadikan kebutuhan akan air bersih di Kabupaten Bangli menjadi semakin meningkat. Kebutuhan air bersih yang terus meningkat tersebut harus diimbangi pula dengan menyiapkan fasilitas yang memadai untuk memaksimalkan pelayanan, penyediaan, dan pendistribusian akan air bersih, yang dimana kegiatan tersebut dapat dilaksanakan oleh Perusahaan Daerah Air Minum atau PDAM.

Pihak PDAM Kabupaten Bangli dalam melangsungkan kegiatan pendistribusian air bersih secara maksimal serta menyiapkan fasilitas yang memadai memerlukan penyesuaian tarif dasar air, yang dimana tarif air sendiri sangat beragam untuk pelanggan di masing-masing golongan. Pada tahun 2013, Pemerintah Kabupaten Bangli beserta PDAM Kabupaten Bangli sepakat untuk membuat kebijakan baru terkait dengan kenaikan tarif air bersih di Kecamatan Bangli dan Tembuku. PDAM Kabupaten Bangli menentukan tarif melalui kajian-kajian yang berdasarkan kepada tingkat kebutuhan masyarakat di Kabupaten Bangli, dengan memperhatikan inflasi serta biaya yang telah dikeluarkan untuk produksi air tersebut. Tarif merupakan salah satu elemen yang penting bagi sebuah Perusahaan Air Minum (PAM), sehingga tarif perlu diperbaharui disetiap tahunnya. Meningkatkan kapasitas produksi air bersih di suatu daerah agar dapat mengimbangi pertumbuhan pelanggan penggunanya tentu tidak memerlukan tarif yang sedikit. Apabila sebuah Perusahaan Air Minum (PAM) masih menetapkan tarif yang terlalu rendah, maka akan berdampak kepada terganggunya pembangunan beragam infrastruktur yang terdapat di sebuah Perusahaan Air Minum (Andawayanti, Bisri, and Ainin 2010; Suminar 2016).

PDAM harus menaikkan tarif dasar air karena merupakan salah satu persyaratan PDAM dalam hal restrukturisasi hutang. Perhitungan dan penetapan tarif dasar air didasarkan pada prinsipprinsip, yaitu: keterjangkauan dan keadilan, mutu pelayanan, pemulihan biaya secara penuh, efisiensi pemakaian air, transparansi, akuntabilitas dan perlindungan air baku. Kenaikan tarif air di dua kecamatan tersebut sebesar $118 \%$, yang dimana sebelum terjadinya kenaikan tarif pada pelanggan golongan non niaga atau rumah tangga untuk pemakaian air bersih di atas $10 \mathrm{~m}^{3}$ dikenakan biaya rata-rata sebesar Rp. 1,650 s/d Rp. 1,750 per $\mathrm{m}^{3}$-nya, sedangkan setelah diberlakukannya kebijakan baru tersebut, yaitu pada Bulan Mei 2013 tarif airnya berubah menjadi Rp. 3,700 per $\mathrm{m}^{3}$-nya (Kabupaten Bangli 2019b).

Dampak dari kenaikan tarif tersebut dapat diketahui dari penelitian mengenai analisis perubahan penggunaan air bersih per-orang/hari yang berdasarkan hasil survei dan penggunaan air rata-rata liter per-orang/hari berdasarkan ketetapan PDAM sebelum dan sesudah terjadi kenaikan tarif (Rumahorbo 2009; Yoga Pratama, Norken, and Suryantara 2013). Data yang digunakan dalam penelitian ini adalah data primer dari hasil survei, yang dimana survei tersebut terkait dengan ratarata jumlah anggota keluarga/SR di Kecamatan Bangli dan Tembuku, serta data sekunder yang dipakai berasal dari PDAM Kabupaten Bangli. Data sekunder yang berasal dari PDAM Kabupaten Bangli diambil dari tahun 2008 s/d 2012, yaitu sebelum terjadinya kenaikan tarif, dan $2013 \mathrm{~s} / \mathrm{d}$ 2018, yaitu sesudah terjadinya kenaikan tarif. Tujuan dari penelitian ini adalah untuk mengetahui penggunaan air bersih oleh pelanggan rumah tangga atau non niaga berdasarkan hasil survei dan berdasarkan ketetapan PDAM di kedua kecamatan tersebut dari sebelum dan sesudah terjadi kenaikan tarif, yang nantinya dapat dijadikan sebagai acuan oleh PDAM dalam menaikkan tarif air bersih di tahun-tahun mendatang.

\section{Material dan Metode}

Air bersih menurut Permenkes RI No. 416/Menkes/PER/IX/1990 merupakan air yang dipakai untuk memenuhi kebutuhan sehari-hari serta layak untuk diminum setelah melalui proses perebusan atau proses pemasakan. Menurut ketentuan badan dunia World Health Organization 
(WHO), Departemen Kesehatan, serta ketentuan dari pihak APHA (American Public Health Association atau Asosiasi Kesehatan Masyarakat AS), baik atau tidaknya air dalam kehidupan makhluk hidup ditentukan berdasarkan atas beberapa persyaratan, seperti persyaratan kualitas, kuantitas, kontinuitas, dan keterjangkauannya (Rahmanian et al. 2015). Persyaratan secara kualitas itu meliputi: kualitas secara fisik, kimia, biologi, dan radiologi, sedangkan persyaratan kuantitas berkaitan dengan jumlah air baku yang tersedia (Jalali 2019; Rohmaningsih, Sholichin, and Haribowo 2017). Selain itu, penyediaan air bersih juga harus memenuhi persyaratan secara kontinuitas dimana jumlah air bersih yang direncanakan dapat memenuhi kebutuhan selama 24 jam serta memenuhi persyaratan keterjangkauan terutama terkait dengan harga air minum bagi masyarakat penggunanya. Kemampuan masyarakat dalam pembayaran tarif air minum diupayakan dengan mempertimbangkan bahwa pengeluaran rumah tangga untuk air minum tidak melampaui 4\% dari pendapatan bulanan keluarga (Kementerian Dalam Negeri 2016).

Penyediaan air minum adalah suatu usaha dalam menyediakan air bersih yang layak pakai untuk dapat memenuhi kebutuhan masyarakat disetiap harinya agar tercapai kehidupan yang sehat, bersih, dan produktif. Sistem Penyediaan Air Minum yang disingkat dengan SPAM merupakan sebuah sarana dan prasarana untuk menyediakan air minum. Penyelenggaraan SPAM adalah serangkaian kegiatan dalam melaksanakan pengembangan dan pengelolaan sarana dan prasarana yang mengikuti proses dasar manajemen untuk penyediaan air minum kepada masyarakat (Kementerian Sekretariat Negara Republik Indonesia 2015).

Pelanggan pengguna air bersih menurut klasifikasi yang sudah dilakukan oleh PDAM Kabupaten Bangli dari tahun 2008 tersebut meliputi (Kabupaten Bangli 2019a):

1. Golongan non niaga, yang dimana golongan non niaga tersebut merupakan rumah tangga. Pihak PDAM menetapkan untuk rata-rata jumlah anggota keluarga dalam Sambungan Rumah (SR) di Kecamatan Bangli hanya sebanyak 6 orang disetiap rumah, kemudian untuk Kecamatan Tembuku hanya sebanyak 7 orang disetiap rumahnya. Penelitian ini akan lebih difokuskan pada pelanggan non niaga, yang dimana jumlah dari pelanggan penggunanya terbagi lagi atas beberapa area ditiap-tiap kecamatan.

2. Golongan niaga, yang meliputi: instansi pemerintah, hotel, restoran, bengkel, tempat hiburan, importir atau eksportir pasar swalayan, rumah sakit swasta tipe $\mathrm{A} / \mathrm{B}$, pompa bensin, toko besar/kecil, mini market, klinik-klinik swasta, kantor perusahaan milik swasta dan warung.

3. Golongan sosial umum adalah pelanggan yang setiap harinya melayani kepentingan umum, khususnya bagi masyarakat yang berpenghasilan rendah, antara lain: kamar mandi umum, kran umum, dan terminal air.

4. Golongan sosial khusus adalah pelanggan yang setiap harinya melayani kepentingan umum, serta mendapatkan sumber dana sebagian dari kegiatannya, antara lain: pesantren, yayasan sosial, tempat pertemuan (balai banjar, balai subak), dan tempat ibadah.

Badan dunia United Nations Educational Scientific and Cultural Organization atau UNESCO sendiri pada tahun 2002 telah memutuskan atas hak dasar manusia terkait dengan kebutuhan air bersih dalam penggunaan per orang per harinya di kota-kota besar hanya sebanyak 150 liter/org/hari. Direktorat Jendral Cipta Karya Departemen Pekerjaan Umum (1998) juga membagi standar kebutuhan air bersih tersebut berdasarkan lokasi wilayahnya, antara lain (Dwi, Tanudjaja, and Hendratta 2016):

1. Daerah pedesaan ditetapkan kebutuhan air bersihnya sebanyak 60 liter/orang/hari.

2. Daerah kota-kota kecil ditetapkan kebutuhan air bersihnya sebanyak 90 liter/orang/hari.

3. Daerah kota-kota sedang ditetapkan kebutuhan air bersihnya sebanyak 130 liter/orang/ hari.

4. Daerah kota-kota besar ditetapkan kebutuhan air bersihnya sebanyak 150 liter/orang/hari.

5. Daerah kota-kota metropolitan ditetapkan kebutuhan air bersihnya sebanyak 160 liter/orang/hari.

Tarif air merupakan kebijakan terkait harga jual air bersih dalam setiap meter kubik $\left(\mathrm{m}^{3}\right)$ atau satuan volume lainnya yang disesuaikan dengan keputusan Kepala Daerah setempat dengan pihak PDAM yang bersangkutan (Kemendagri 2006). Besarnya tarif air disuatu daerah merupakan kesepakatan bersama antara pihak penyedia air bersih atau PDAM dengan pelanggan pengguna jasa layanan air bersih tersebut. Perhitungan dan penetapan tarif air didasarkan pada beberapa 
prinsip, antara lain: keterjangkauan, keadilan, mutu pelayanan, pemulihan biaya secara penuh, efisiensi pemakaian air, transparansi, akuntabilitas, dan perlindungan air baku.

Teknik sampling yang dipakai dalam penelitian ini adalah Probability Sampling dengan teknik statistik Simple Random Sampling. Teknik statistiknya dikatakan simple atau sederhana karena pengambilan sampel dari anggota populasinya dilakukan secara acak, tanpa memperhatikan strata yang ada di dalam populasi tersebut. Penelitian ini mulai dilakukan pada tanggal 17 Januari 2019 sampai dengan 15 Juni 2019 mengambil lokasi di Kabupaten Bangli pada Kecamatan Bangli dan Tembuku. Kecamatan Bangli terbagi lagi atas beberapa area, yang dimana jumlah area pada kecamatan tersebut sebanyak 5. Area 1 terdiri dari Desa Pengotan dan Landih, kemudian Area 2 merupakan Desa Kayubihi, Area 3 terdiri dari Desa Kubu dan Cempaga, Area 4 terdiri dari Desa Kawan dan Bebalang, dan yang terakhir Area 5 terdiri dari Desa Taman Bali dan Bunutin, sedangkan untuk Kecamatan Tembuku jumlah Area sebanyak 4, yang dimana pada Area 6 merupakan Desa Yangapi, kemudian Area 7 merupakan Desa Peninjoan, Area 8 terdiri dari Desa Tembuku dan Jahem, yang terakhir Area 9 terdiri dari Desa Bangbang dan Undisan.

Jenis data yang digunakan dalam penelitian ini adalah data primer dan data sekunder. Data primer tersebut didapat melalui hasil survei langsung ke pelanggan PDAM golongan non niaga atau rumah tangga di Kecamatan Bangli dan Tembuku, sedangkan untuk data sekunder didapat dari pihak PDAM Kabupaten Bangli, yang dimana data tersebut diambil dari tahun 2008 s/d 2018 atau dari tahun sebelum dan sesudah terjadi kenaikan tarif. Adapun hal-hal yang dapat dilakukan untuk mendapatkan jawaban dari tujuan penelitian ini adalah sebagai berikut:

1. Menghitung besarnya penggunaan air bersih rata-rata liter per-orang/hari berdasarkan hasil survei di Kecamatan Bangli dan Tembuku untuk tiap-tiap areanya sebelum dan sesudah terjadi kenaikan tarif,

2. Menghitung besarnya penggunaan air bersih rata-rata per-orang/hari berdasarkan ketetapan PDAM untuk jumlah anggota keluarga/SR di Kecamatan Bangli dan Tembuku untuk tiap-tiap areanya sebelum dan sesudah terjadi kenaikan tarif.

Penggunaan air bersih liter per orang/hari berdasarkan hasil survei dapat dihitung dengan menggunakan persamaan:

$$
\frac{\text { Jumlah penggunaan air rata }- \text { rata / hari }}{\text { Jumlahanggota keluarga }(1 S R)}
$$

dengan:

- Jumlah anggota keluarga dalam 1 SR tersebut didapat dari nilai rata-rata jumlah anggota keluarga pada tiap-tiap area di Kecamatan Bangli dan Tembuku. Jumlah anggota keluarga didapat dari survei langsung.

- Jumlah penggunaan air bersih rata-rata/hari yang dipakai adalah hasil bagi dari penggunaan air bersih per bulan ditiap-tiap area dengan 31 hari kalender, kemudian satuannya dirubah menjadi liter.

\section{Hasil dan Pembahasan}

Setelah diketahui rumus untuk menghitung penggunaan air bersih liter per orang/hari berdasarkan hasil survey dan berdasarkan ketetapan PDAM, maka langkah selanjutnya adalah mengetahui rata-rata jumlah anggota keluarga/SR di masing-masing kecamatan sebanyak 80 sampel di Kecamatan Bangli dan sebanyak 75 sampel di Kecamatan Tembuku dengan data ratarata jumlah anggota keluarga terdapat pada Tabel 1 dan 2. Penggunaan air bersih rata-rata pada area 1,2,3,4 dan 5 sebelum terjadi kenaikan tarif PDAM, yaitu pada tahun 2008 s/d 2012 mengalami kenaikan yang tidak begitu besar sehingga perbedaan dari tahun ke tahunnya terlihat sangat tipis sebesar $1.16 \%$. 
Tabel 1. Rata-rata jumlah anggota keluarga/SR di Kecamatan Bangli

\begin{tabular}{cc}
\hline Area & $\begin{array}{c}\text { Rata-rata jumlah anggota } \\
\text { keluarga/1 SR di } \\
\text { Kecamatan Bangli (org) }\end{array}$ \\
\hline 1 & 7 \\
2 & 7 \\
3 & 7 \\
4 & 6 \\
5 & 6 \\
\hline
\end{tabular}

Tabel 2. Rata-rata jumlah anggota keluarga/SR di Kecamatan Tembuku

\begin{tabular}{cccccc}
\hline & \multicolumn{5}{c}{ Penggunaan Air Bersih (Liter/Org/Hari) } \\
\cline { 2 - 6 } Area & \multicolumn{5}{c}{ Sebelum Terjadi Kenaikan Tarif } \\
\cline { 2 - 6 } & 2008 & 2009 & 2010 & 2011 & 2012 \\
\hline 1 & 209.40 & 209.68 & 211.34 & 211.84 & 212.12 \\
2 & 193.69 & 193.82 & 194.70 & 195.16 & 195.62 \\
3 & 184.47 & 184.84 & 185.48 & 185.62 & 185.99 \\
4 & 188.66 & 190.05 & 190.43 & 190.59 & 190.65 \\
5 & 166.94 & 167.04 & 168.03 & 168.22 & 169.75 \\
\hline
\end{tabular}

Tabel 3. Penggunaan air bersih rata-rata (liter/org/hari) sebelum terjadi kenaikan tarif di Kecamatan Bangli berdasarkan hasil survei

\begin{tabular}{cccccc}
\hline & \multicolumn{5}{c}{ Penggunaan Air Bersih (Liter/Org/Hari) } \\
\cline { 2 - 6 } Area & \multicolumn{5}{c}{ Sebelum Terjadi Kenaikan Tarif } \\
\cline { 2 - 6 } & 2008 & 2009 & 2010 & 2011 & 2012 \\
\hline 1 & 209.40 & 209.68 & 211.34 & 211.84 & 212.12 \\
2 & 193.69 & 193.82 & 194.70 & 195.16 & 195.62 \\
3 & 184.47 & 184.84 & 185.48 & 185.62 & 185.99 \\
4 & 188.66 & 190.05 & 190.43 & 190.59 & 190.65 \\
5 & 166.94 & 167.04 & 168.03 & 168.22 & 169.75 \\
\hline
\end{tabular}

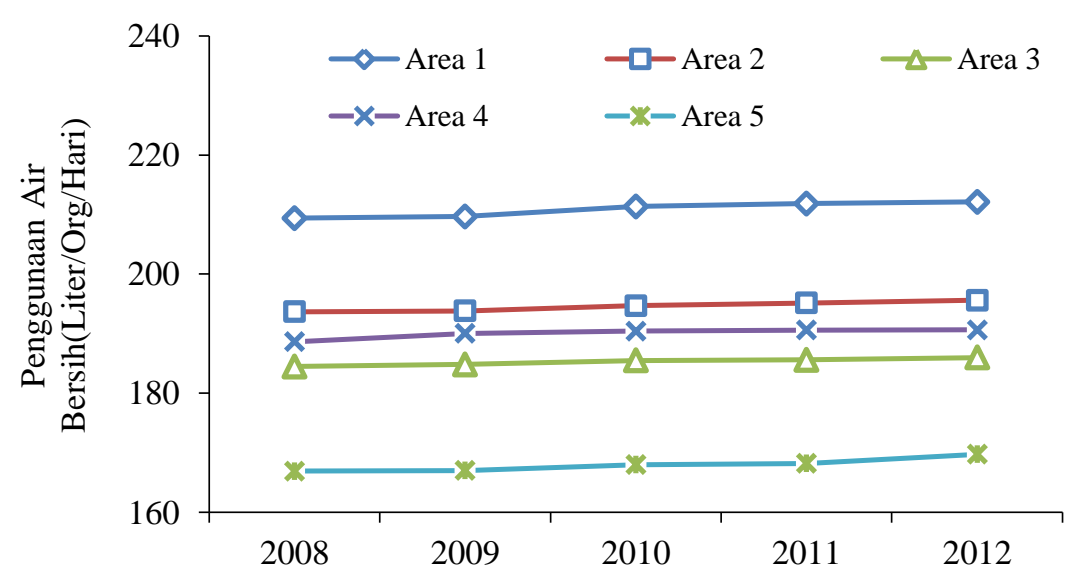

Gambar 1. Grafik penggunaan air bersih rata-rata (liter/org/hari) sebelum terjadi kenaikan tarif di Kecamatan Bangli berdasarkan hasil survei 
Dari sampel yang diteliti, penggunaan air bersih rata-rata per orang/hari setiap bulan Desember untuk masing-masing tahunnya paling besar terdapat pada Area 1, sedangkan penggunaan air bersih rata-rata terkecil terdapat pada Area 5. Pola penggunaan air bersihnya meningkat, akan tetapi peningkatan yang terjadi tidak terlalu banyak, sehingga trend yang terjadi pun terlihat seperti Gambar 1. Penggunaan air bersih rata-rata pada area 1,2,3,4 dan 5 sesudah terjadi kenaikan tarif PDAM atau pada tahun $2013 \mathrm{~s} / \mathrm{d} 2018$ mengalami penurunan rata-rata $25.28 \%$.

Tabel 4. Penggunaan air bersih rata-rata (liter/orang/hari) sesudah terjadi kenaikan tarif di Kecamatan Bangli berdasarkan hasil survei

\begin{tabular}{ccccccc}
\hline & \multicolumn{6}{c}{ Penggunaan Air Bersih (Liter/Org/Hari) } \\
\cline { 2 - 7 } Area & \multicolumn{5}{c}{ Sesudah Terjadi Kenaikan Tarif } \\
\cline { 2 - 7 } & 2013 & 2014 & 2015 & 2016 & 2017 & 2018 \\
\hline 1 & 185.3 & 179.8 & 175.7 & 167.5 & 161.4 & 152.6 \\
2 & 164.2 & 157.1 & 153.2 & 139.1 & 132.4 & 118.0 \\
3 & 163.4 & 150.5 & 138.9 & 132.5 & 121.3 & 115.4 \\
4 & 173.1 & 167.3 & 160.1 & 146.9 & 138.0 & 124.5 \\
5 & 136.8 & 134.8 & 131.1 & 123.7 & 116.8 & 105.1 \\
\hline
\end{tabular}

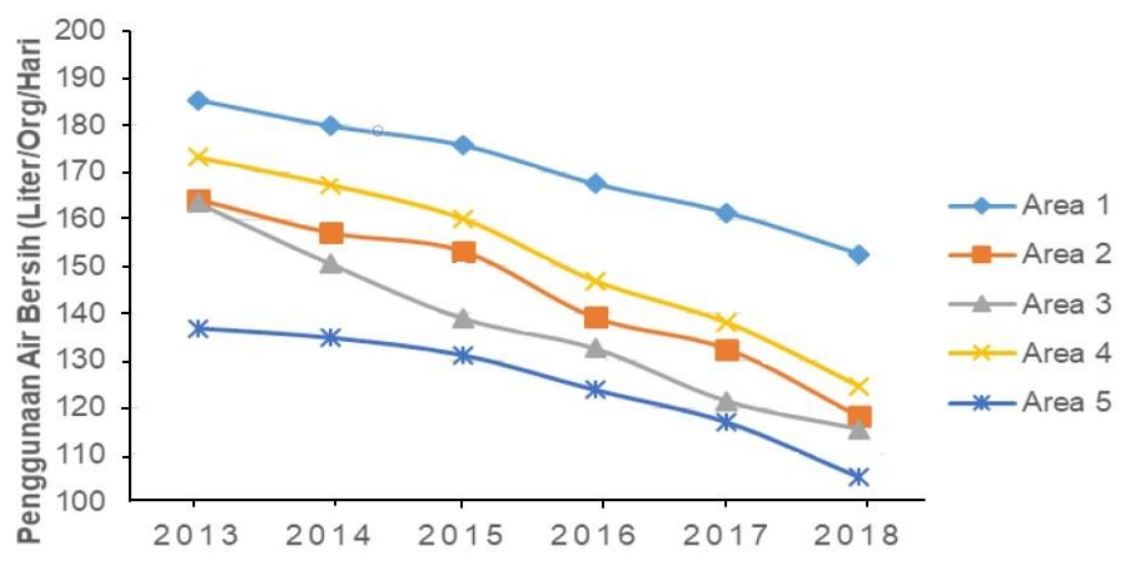

Gambar 2. Grafik penggunaan air bersih rata-rata (liter/orang/hari) sesudah terjadi kenaikan tarif di Kecamatan Bangli berdasarkan hasil survei

Tabel 5. Penggunaan air bersih rata-rata (liter/orang/hari) sebelum terjadi kenaikan tarif di Kecamatan Bangli berdasarkan hasil survei

\begin{tabular}{cccccc}
\hline & \multicolumn{5}{c}{ Penggunaan Air Bersih (Liter/Org/Hari) } \\
\cline { 2 - 6 } Area & \multicolumn{5}{c}{ Sebelum Terjadi Kenaikan Tarif } \\
\cline { 2 - 6 } & 2008 & 2009 & 2010 & 2011 & 2012 \\
\hline 6 & 190.37 & 192.72 & 193.92 & 194.52 & 196.45 \\
7 & 221.94 & 222.26 & 223.01 & 223.33 & 225.11 \\
8 & 210.70 & 212.42 & 213.98 & 215.11 & 216.72 \\
9 & 141.10 & 142.26 & 144.84 & 145.68 & 150.84 \\
\hline
\end{tabular}

Dari sampel yang diteliti, untuk Area 1 rata-rata penggunaan airnya terlihat paling besar, sedangkan penggunaan air bersih rata-rata terkecilnya terdapat pada Area 5. Pola penggunaan air bersihnya menurun secara signifikan, sehingga tren yang terjadi pun terlihat seperti Gambar 2 . Penggunaan air bersih rata-rata pada area 6,7,8 dan 9 sebelum terjadi kenaikan tarif PDAM, yaitu 
pada tahun 2008 s/d 2012 mengalami kenaikan sebesar 3.43\% dan penggunaan air bersih rata-rata setiap Bulan Desember untuk masing-masing tahunnya paling besar terdapat pada Area 7, sedangkan penggunaan air bersih rata-rata terkecilnya terdapat pada Area 9. Pola penggunaan air bersihnya meningkat, akan tetapi peningkatan yang terjadi tidak terlalu banyak, sehingga tren yang terjadi pun terlihat seperti Gambar 3.

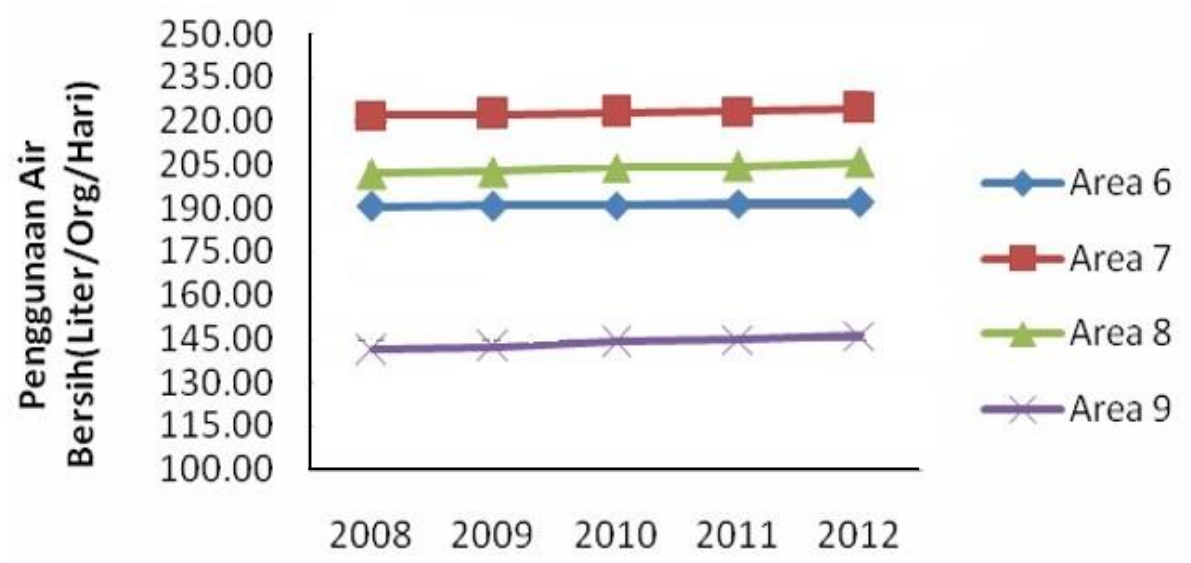

Gambar 3. Grafik penggunaan air bersih rata-rata (liter/orang/hari) sebelum terjadi kenaikan tarif di Kecamatan Bangli berdasarkan hasil survei

Tabel 6. Penggunaan air bersih rata-rata (liter/orang/hari) sesudah terjadi kenaikan tarif di Kecamatan Bangli berdasarkan hasil survei

\begin{tabular}{ccccccc}
\hline & \multicolumn{6}{c}{ Penggunaan Air Bersih (Liter/Org/Hari) } \\
\cline { 2 - 7 } Area & \multicolumn{5}{c}{ Sesudah Terjadi Kenaikan Tarif } \\
\cline { 2 - 7 } & 2013 & 2014 & 2015 & 2016 & 2017 & 2018 \\
\hline 6 & 204.2 & 211.6 & 215.3 & 218.6 & 225.4 & 230.9 \\
7 & 232.7 & 237.4 & 246.3 & 252.3 & 258.2 & 268.9 \\
8 & 222.5 & 231.3 & 237.0 & 242.5 & 256.8 & 261.1 \\
9 & 163.9 & 173.4 & 176.3 & 182.0 & 191.3 & 196.3 \\
\hline
\end{tabular}

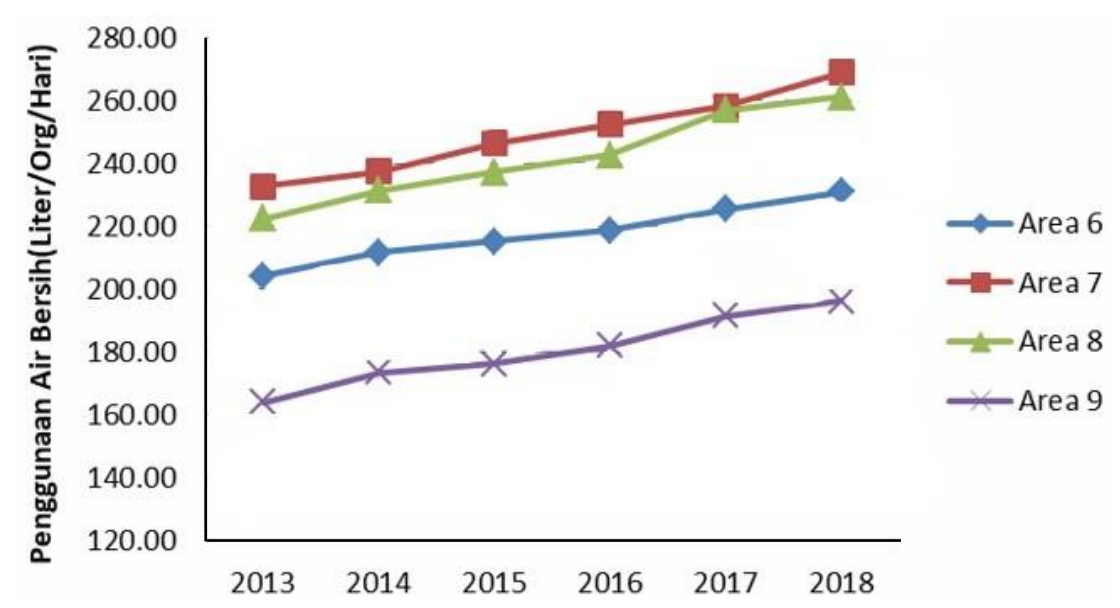

Gambar 4. Grafik Penggunaan air bersih rata-rata (liter/orang/hari) sesudah terjadi kenaikan tarif di Kecamatan Bangli berdasarkan hasil survei 
Penggunaan air bersih rata-rata pada area 6,7,8 dan 9 sesudah terjadi kenaikan tarif PDAM, yaitu pada tahun $2013 \mathrm{~s} / \mathrm{d} 2018$ mengalami kenaikan sebesar 14.08\%. Rata-rata penggunaan air bersih setiap Bulan Desember untuk tiap tahunnya paling besar terdapat di Area 7, sedangkan penggunaan air bersih rata-rata terkecil terdapat pada Area 9. Pola penggunaan air bersihnya meningkat sangat signifikan, sehingga trend yang terjadi pun terlihat seperti Gambar 4.

Tabel 7. Penggunaan air bersih rata-rata (liter/orang/hari) sebelum terjadi kenaikan tarif di Kecamatan Bangli berdasarkan ketetapan PDAM

\begin{tabular}{cccccc}
\hline & \multicolumn{5}{c}{ Penggunaan Air Bersih (Liter/Org/Hari) } \\
\cline { 2 - 6 } Area & \multicolumn{5}{c}{ Sebelum Terjadi Kenaikan Tarif } \\
\cline { 2 - 6 } & 2008 & 2009 & 2010 & 2011 & 2012 \\
\hline 1 & 244.30 & 244.62 & 246.56 & 247.15 & 247.47 \\
2 & 225.97 & 226.13 & 227.15 & 227.69 & 228.23 \\
3 & 215.22 & 215.65 & 216.40 & 216.56 & 216.99 \\
4 & 188.66 & 190.05 & 190.43 & 190.59 & 191.05 \\
5 & 166.94 & 167.04 & 167.74 & 167.92 & 168.05 \\
\hline
\end{tabular}

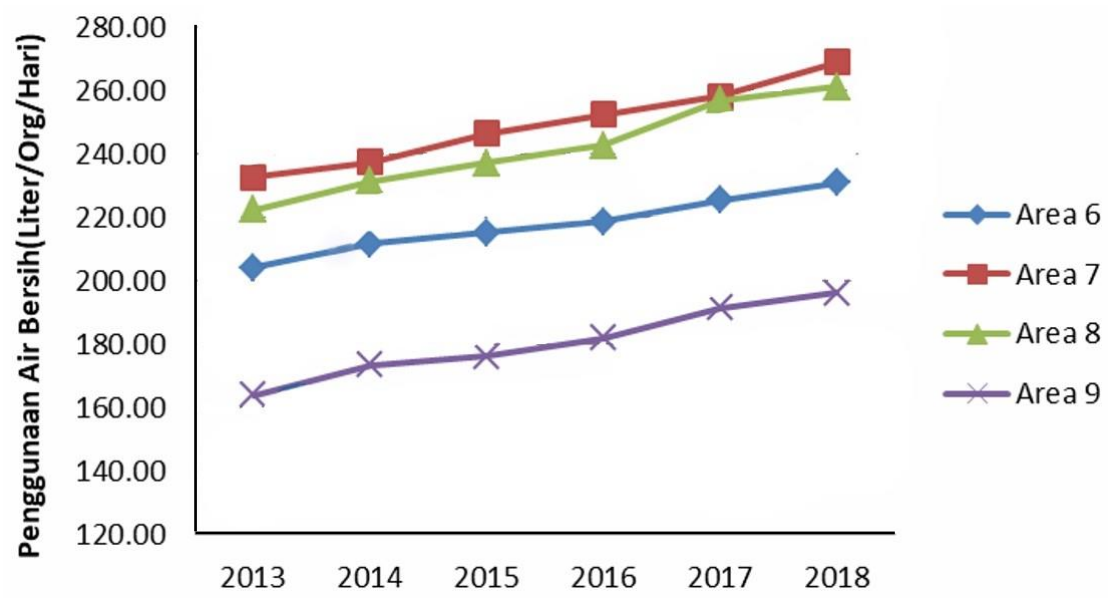

Gambar 5. Grafik penggunaan air bersih rata-rata (liter/orang/hari) sebelum terjadi kenaikan tarif di Kecamatan Bangli berdasarkan ketetapan PDAM

Tabel 8. Penggunaan air bersih rata-rata (liter/orang/hari) sesudah terjadi kenaikan tarif di Kecamatan Bangli berdasarkan ketetapan PDAM

\begin{tabular}{ccccccc}
\hline & \multicolumn{6}{c}{ Penggunaan Air Bersih (Liter/Org/Hari) } \\
\cline { 2 - 7 } Area & \multicolumn{5}{c}{ Sesudah Terjadi Kenaikan Tarif } \\
\cline { 2 - 7 } & 2013 & 2014 & 2015 & 2016 & 2017 & 2018 \\
\hline 1 & 216.2 & 209.8 & 205.0 & 195.4 & 188.3 & 178.0 \\
2 & 191.6 & 183.3 & 178.7 & 162.3 & 154.5 & 137.7 \\
3 & 190.7 & 175.6 & 162.1 & 154.6 & 141.6 & 134.7 \\
4 & 173.1 & 167.3 & 160.1 & 146.9 & 138.0 & 124.5 \\
5 & 136.9 & 134.8 & 131.1 & 123.7 & 116.8 & 105.0 \\
\hline
\end{tabular}

Penggunaan air bersih rata-rata pada area 1,2,3,4 dan 5 sebelum terjadi kenaikan tarif PDAM, yaitu pada tahun 2008 s/d 2012 sebagian besar mengalami kenaikan tipis sebesar 1\%. Ketetapan jumlah anggota keluarga/SR berdasarkan PDAM Kabupaten Bangli untuk Kecamatan Bangli adalah 6 orang, jadi untuk seluruh rata-rata penggunaan air bersih/hari tersebut dibagi dengan 6 . 
Rata-rata penggunaan air bersih setiap Bulan Desember untuk tiap tahunnya paling besar terdapat di Area 1, dan terkecil pada Area 5. Pola penggunaan air bersihnya meningkat, akan tetapi peningkatan yang terjadi tidak terlalu banyak, sehingga trend yang terjadi pun terlihat seperti Gambar 5.

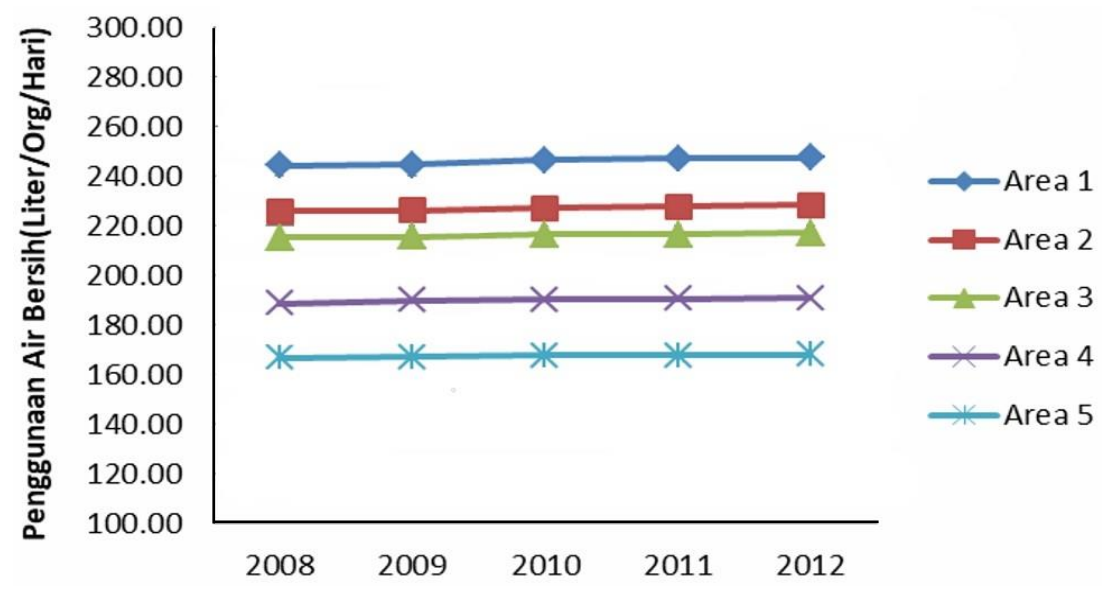

Gambar 6. Grafik penggunaan air bersih rata-rata (liter/orang/hari) sesudah terjadi kenaikan tarif di Kecamatan Bangli berdasarkan ketetapan PDAM

Tabel 9. Penggunaan air bersih rata-rata (liter/orang/hari) sebelum terjadi kenaikan tarif di Kecamatan Tembuku berdasarkan ketetapan PDAM

\begin{tabular}{cccccc}
\hline & \multicolumn{5}{c}{ Penggunaan Air Bersih (Liter/Org/Hari) } \\
\cline { 2 - 6 } Area & \multicolumn{5}{c}{ Sebelum Terjadi Kenaikan Tarif } \\
\cline { 2 - 6 } & 2008 & 2009 & 2010 & 2011 & 2012 \\
\hline 6 & 190.37 & 192.72 & 193.92 & 194.52 & 196.45 \\
7 & 190.23 & 190.51 & 191.15 & 191.43 & 192.95 \\
8 & 180.60 & 182.07 & 183.41 & 184.38 & 185.76 \\
9 & 100.78 & 101.61 & 103.46 & 104.06 & 107.74 \\
\hline
\end{tabular}

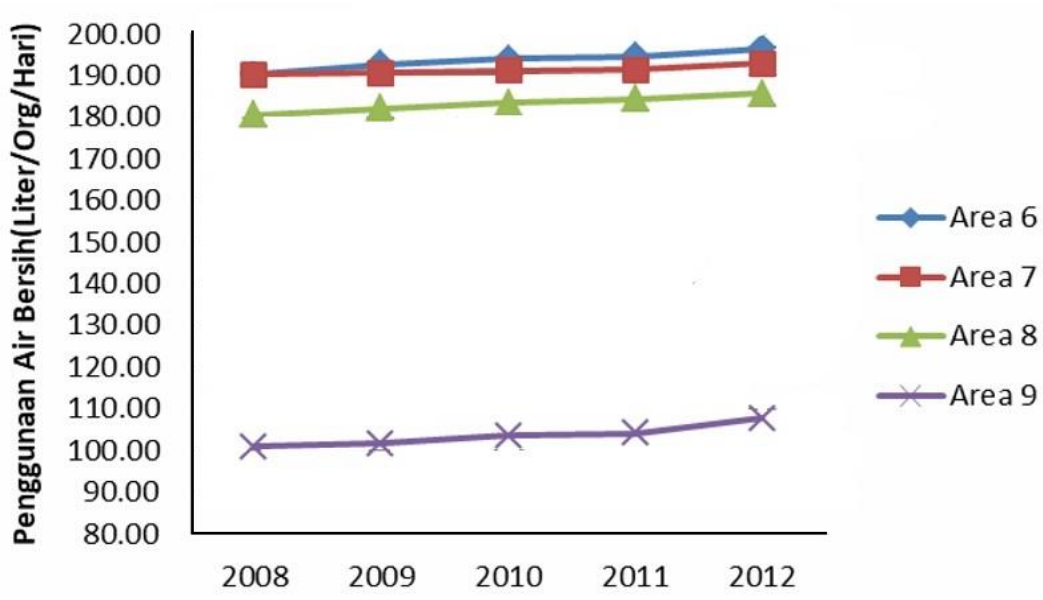

Gambar 7. Grafik penggunaan air bersih rata-rata (liter/orang/hari) sebelum terjadi kenaikan tarif di Kecamatan Tembuku berdasarkan ketetapan PDAM

Penggunaan air bersih rata-rata pada area 1,2,3,4 dan 5 sesudah terjadi kenaikan tarif PDAM atau pada tahun $2013 \mathrm{~s} / \mathrm{d} 2018$ mengalami penurunan sebesar 25.31\%. Ketetapan jumlah anggota keluarga/SR berdasarkan PDAM Kabupaten Bangli untuk Kecamatan Bangli adalah 6 orang, jadi 
untuk seluruh rata-rata penggunaan air bersih/hari tersebut dibagi dengan 6. Rata-rata penggunaan air bersih setiap Bulan Desember untuk tiap tahunnya paling besar terdapat di Area 1, dan terkecil pada Area 5. Pola penggunaan air bersihnya menurun secara signifikan, sehingga trend yang terjadi pun terlihat seperti Gambar 6.

Penggunaan air bersih rata-rata pada area 6,7,8 dan 9 sebelum terjadi kenaikan tarif PDAM, yaitu pada tahun 2008 s/d 2012 mengalami peningkatan sebesar 3.44\%. Ketetapan jumlah anggota keluarga/SR berdasarkan PDAM Kabupaten Bangli untuk Kecamatan Tembuku adalah 7 orang, jadi untuk seluruh rata-rata penggunaan air bersih/hari tersebut dibagi dengan 7 . Rata-rata penggunaan air bersih setiap Bulan Desember untuk tiap tahunnya paling besar terdapat di Area 6, sedangkan penggunaan air bersih rata-rata terkecilnya terdapat pada Area 9. Pola penggunaan air bersihnya meningkat sedikit demi sedikit, sehingga tren yang terjadi pun terlihat seperti Gambar 7 .

Penggunaan air bersih rata-rata pada area 6,7,8 dan 9 sesudah terjadi kenaikan tarif PDAM, yaitu pada tahun 2013 s/d 2018 mengalami kenaikan sebesar 14.7\%. Ketetapan jumlah anggota keluarga/SR berdasarkan PDAM Kabupaten Bangli untuk Kecamatan Tembuku adalah 7 orang, jadi untuk seluruh rata-rata penggunaan air bersih/hari tersebut dibagi dengan 7 . Rata-rata penggunaan air bersih setiap Bulan Desember untuk tiap tahunnya paling besar terdapat di Area 6, sedangkan penggunaan air bersih rata-rata terkecil terdapat pada Area 9. Pola penggunaan air bersihnya meningkat sangat signifikan, sehingga trend yang terjadi pun terlihat seperti Gambar 8 .

Tabel 10. Penggunaan air bersih rata-rata (liter/orang/hari) sesudah terjadi kenaikan tarif di Kecamatan Tembuku berdasarkan ketetapan PDAM

\begin{tabular}{ccccccc}
\hline & \multicolumn{6}{c}{ Penggunaan Air Bersih (Liter/Org/Hari) } \\
\cline { 2 - 7 } Area & \multicolumn{5}{c}{ Sesudah Terjadi Kenaikan Tarif } \\
\cline { 2 - 7 } & 2013 & 2014 & 2015 & 2016 & 2017 & 2018 \\
\hline 6 & 204.2 & 211.6 & 215.3 & 218.6 & 225.4 & 230.9 \\
7 & 199.5 & 203.5 & 211.2 & 216.2 & 221.3 & 230.5 \\
8 & 190.7 & 198.2 & 203.2 & 207.9 & 220.1 & 223.8 \\
9 & 117.1 & 123.9 & 125.9 & 130.0 & 136.9 & 140.2 \\
\hline
\end{tabular}

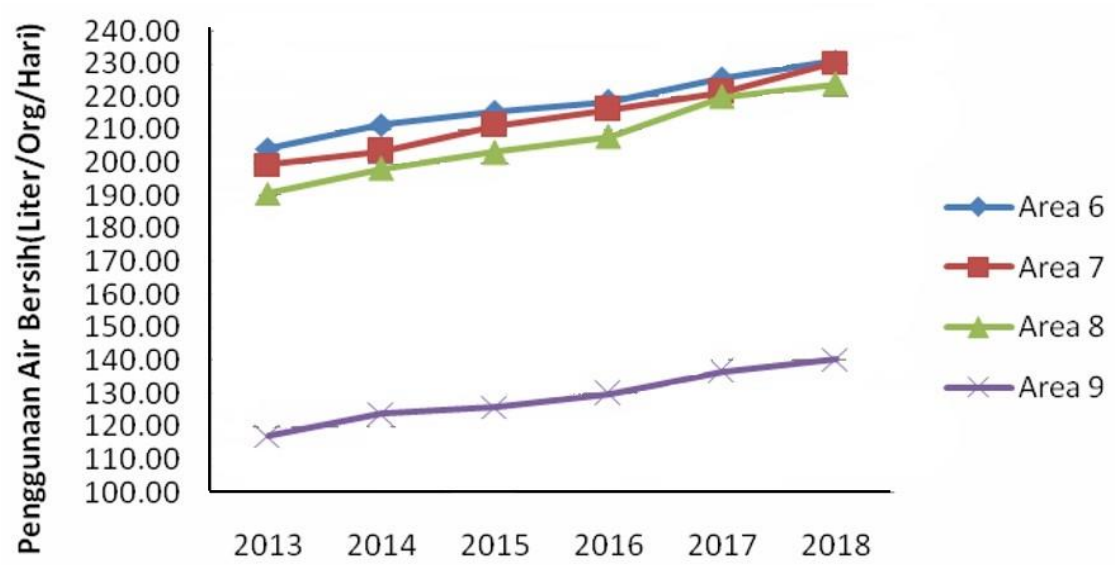

Gambar 8. Grafik penggunaan air bersih rata-rata (liter/orang/hari) sesudah terjadi kenaikan tarif di Kecamatan Tembuku berdasarkan ketetapan PDAM

\section{Kesimpulan}

Jumlah penggunaan air bersih rata-rata pada tahun $2008 \mathrm{~s} / \mathrm{d} 2012$ berdasarkan hasil survei pada setiap area untuk Kecamatan Bangli sebelum kenaikan tarif mengalami kenaikan sebesar $1.16 \%$. Penggunaan air bersih terbesar terdapat pada Area 1, sedangkan yang terkecil pada Area 5, kemudian untuk jumlah penggunaan air bersih rata-rata berdasarkan ketetapan PDAM disetiap area untuk Kecamatan Bangli sebelum kenaikan tarif, yaitu pada tahun 2008 s/d 2012 juga mengalami kenaikan 
sebesar 1\%. Jumlah anggota keluarga secara ketetapan PDAM di Kecamatan Bangli sebanyak 6 orang. Jumlah penggunaan air bersih rata-rata pada tahun $2013 \mathrm{~s} / \mathrm{d} 2018$ berdasarkan hasil survei pada setiap area untuk Kecamatan Bangli sesudah kenaikan tarif mengalami penurunan sebesar 25.28\%. Penggunaan air bersih terbesar terdapat pada Area 1, sedangkan yang terkecil pada Area 5, kemudian untuk jumlah penggunaan air bersih rata-rata berdasarkan ketetapan PDAM untuk Kecamatan Bangli sesudah kenaikan tarif pada tahun $2008 \mathrm{~s} / \mathrm{d} 2012$ juga mengalami penurunan sebesar 25.31\%. Jumlah anggota keluarga secara ketetapan PDAM di Kecamatan Bangli sebanyak 6 orang. Jumlah penggunaan air bersih rata-rata pada tahun $2008 \mathrm{~s} / \mathrm{d} 2012$ berdasarkan hasil survei pada setiap area untuk Kecamatan Tembuku sebelum kenaikan tarif mengalami peningkatan sebesar $3.43 \%$, sehingga pola penggunaan airnya pun mengalami kenaikan. Penggunaan air bersih terbesar terdapat pada Area 7, kemudian untuk jumlah penggunaan air bersih rata-rata berdasarkan ketetapan PDAM pada setiap area untuk Kecamatan Tembuku sebelum kenaikan tarif naik sebesar 3.44\%, namun penggunaan air bersih terbesar terdapat pada Area 6. Jumlah anggota keluarga secara ketetapan PDAM di Kecamatan Tembuku sebanyak 7 orang. Jumlah penggunaan air bersih rata-rata berdasarkan hasil survei pada setiap area untuk Kecamatan Tembuku sesudah kenaikan tarif, yaitu pada tahun 2013 s/d 2018 juga mengalami peningkatan sebesar $14.08 \%$. Pola penggunaannya pun meningkat dari tahun ke tahun untuk seluruh area. Jumlah penggunaan air bersih paling besar terdapat pada Area 7, kemudian untuk jumlah penggunaan air bersih rata-rata berdasarkan ketetapan PDAM pada setiap area untuk Kecamatan Tembuku sesudah kenaikan tarif juga meningkat sebesar 14.07\%, namun penggunaan air bersih terbesar terdapat pada Area 6. Jumlah anggota keluarga secara ketetapan PDAM di Kecamatan Tembuku sebanyak 7 orang.

\section{Daftar Pustaka}

Andawayanti, Ussy, Mohammad Bisri, and Cahyani Ainin. 2010. "Studi Harga Air Di Pdam Kota Malang." Jurnal Teknik Pengairan 1(2): 1-12.

Dwi, Tirta Yudha Gaib, Lambertus Tanudjaja, and Liany A. Hendratta. 2016. "Perencanaan Peningkatan Kapasitas Produksi Air Bersih Ibukota Kecamatan Nuangan.” Jurnal Sipil Statik 4(8): 481-91.

Jalali, S. 2019. "Persyaratan Kualitas Air Minum Perusahaan Daerah Air Minum (PDAM) Kabupaten Bangli 2013. Tarif Air Berubah Menjadi 3.700 Per-M3nya."

Kabupaten Bangli, PDAM. 2019a. Klasifikasi Pengguna Air Bersih PDAM Kabupaten Bangli.

_.2019b. Perusahaan Daerah Air Minum Kabupaten Bangli Tentang Perubahan Tarif Air Sebesar 118\% Di Kecamatan Bangli Dan Tembuku.

Kemendagri. 2006. Peraturan Menteri Dalam Negeri No. 23 Tahun 2006 Tentang Pedoman Teknis Dan Tata Cara Pengaturan Tarif Air Minum Pada Perusahaan Daerah Air Minum.

Kementerian Dalam Negeri. 2016. Peraturan Menteri Dalam Negeri Republik Indonesia No. 71 Tahun 2016 Tentang Perhitungan Dan Penetapan Tarif Air Minum.

Kementerian Sekretariat Negara Republik Indonesia. 2015. Peraturan Pemerintah Republik Indonesia Nomor 122 Tahun 2015 Tentang Sistem Penyediaan Air Minum.

Rahmanian, N. et al. 2015. "Analysis of Physiochemical Parameters to Evaluate the Drinking Water Quality in the State of Perak, Malaysia." Journal of Chemistry 2015(Cd).

Rohmaningsih, Elin, Mohammad Sholichin, and Riyanto Haribowo. 2017. "Kajian Pengembangan Sistem Penyediaan Air Bersih Pada Daerah Rawan Air Di Desa Sumbersih." Jurnal Teknik Pengairan 8(1): 48-59.

Rumahorbo, Willy. 2009. "Analisis Faktor-Faktor Yang Mempengaruhi Permintaan Air Bersih Di Kecamatan Medan Timur." Universitas Sumatera Utara.

Suminar, Cucum. 2016. "Ini Manfaat Tarif PDAM Yang Lebih Ekonomis."

Yoga Pratama, I Wayan Deny, I Nyoman Norken, and I Putu Gustave Suryantara. 2013. “Analisis Perubahan Penggunaan Air Minum Sebelum Dan Setelah Kenaikan Tarif PDAM Kota Denpasar (Studi Kasus: Denpasar Selatan).” Jurnal Ilmiah Elektronik Infrastruktur Teknik Sipil 2(2): 1-6. 